\title{
Monitoring and Ecotoxicity Assessment of Emerging Contaminants in Wastewater Discharge in the City of Prague (Czech Republic)
}

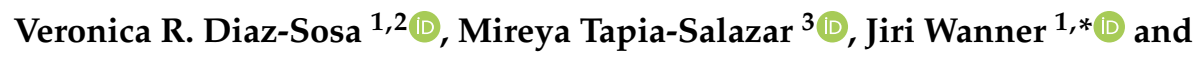 \\ Diana L. Cardenas-Chavez ${ }^{2, *(D)}$ \\ 1 Department of Water Technology and Environmental Engineering, University of Chemistry and Technology \\ Prague, Technická 5, 16628 Praha 6, Czech Republic; verodiso86@gmail.com \\ 2 Tecnologico de Monterrey, School of Engineering and Science, Puebla 72453, Mexico \\ 3 Facultad de Ciencias Biológicas, Universidad Autónoma de Nuevo León, San Nicolás de los Garza 66455, \\ Mexico; mireya.tapiasl@uanl.edu.mx \\ * Correspondence: jiri.wanner@vscht.cz (J.W.); diana.cardenas@tec.mx (D.L.C.-C.)
}

Received: 25 February 2020; Accepted: 6 April 2020; Published: 10 April 2020

\begin{abstract}
Emerging contaminants (ECs) are not monitored nor regulated consistently, but may have negative effects on human health and ecosystem balance. Although pharmaceuticals and personal care products are among the main ECs found in surface and wastewater, their toxicity and fate are currently not sufficiently studied. In this study, we analyzed for the first time a group of 46 ECs in the secondary effluent of the wastewater treatment plants (WWTP) of Prague. Thirty-seven compounds were identified in the discharge to surface water. Three compounds had no toxicology information on Artemia salina: furosemide, hydrochlorothiazide, and tramadol. We performed acute toxicity (LC50) tests and enzyme assays after 24 and $48 \mathrm{~h}$ at room temperature and $28{ }^{\circ} \mathrm{C}$ for these three compounds. LC50 ranged from $225.01 \mathrm{mg} / \mathrm{L}$ for furosemide, the most toxic, up to above $14,000 \mathrm{mg} / \mathrm{L}$ for tramadol. Changes in enzymatic activity for GST, GPx, AChE, and LDH when A. salina were exposed to LC25 for each contaminant were conspicuous and significant in a contaminant-, exposure time-, and temperature-dependent manner. These biochemical markers complement the toxicity profile of these contaminants in aquatic ecosystems and highlight the need for further research on other ECs and their implications, and the regulations required to protect human and ecological health.
\end{abstract}

Keywords: emerging contaminants; Artemia salina; oxidative stress enzymes

\section{Introduction}

In past decades, wastewater moved from being perceived as a threat to public health to being considered as a raw material for energy production and recovery of precious resources, including water itself [1]. Furthermore, water resources started to become scarce in many regions around the world, mainly where the climatic conditions are unfavorable and population and water consumption are increasing. This perspective implies a strict control in the quality of the reused water, such that it does not represent a risk to the environment and health of its users and possible consumers. Most of the research about water quality and its health implications is focused mainly on physicochemical and microbiological parameters, heavy metals, pesticides, and petroleum hydrocarbons. However, recent scientific evidence has redirected attention to a new and growing threat known as emerging contaminants (ECs). These micropollutants are natural or synthetic substances that are not monitored nor regulated in a consistent manner, although they may have adverse effects on human health and ecosystem balance [2,3]. The main concern about these contaminants is that their effects can start manifesting at concentrations as low as micrograms per liter $(\mu \mathrm{g} / \mathrm{L})[3,4]$. Common commercial 
products, such as pharmaceuticals and personal care products (PPCPs) are one of the primary sources of these contaminants. This group includes human and veterinary drugs (e.g., antibiotics, hormones, antidepressants, antihypertensives, analgesics, anti-inflammatories, etc.), food additives, cleaning products, fragrances, and sunscreens, among others. The problem starts when they are disposed into the sewage system, because current wastewater treatment plants (WWTPs) cannot retain, treat, or eliminate the great majority of the ECs reported [5]. Even if appropriate technologies exist, their use is limited because of the incremental cost they represent and the absence of regulations limiting the concentration of the majority of these substances in municipally treated discharge. Discharge and limited wastewater treatment has led to the presence of ECs in water bodies and even drinking water sources around the world $[3,6]$.

Since the adverse effects on human health and ecosystem balance have recently been demonstrated for some of these contaminants [4], and the list of contaminants is extensive, more in vivo studies are needed for the ones with no information available. It is necessary to establish their possible effects along with the concentration at which the repercussions become relevant in ecological, economic, and health terms. Some of the most common organisms employed as animal models for the study of emerging contaminants effects are the fish Danio rerio, the cladoceran Daphnia magna (water flea), bacteria, microalgae, and crustaceans such as Artemia salina (brine shrimp). The latter, aside from its great economic relevance in aquaculture and important role in marine ecological balance, represents an available, fast, simple, and cost-effective option for toxicological tests $[7,8]$. Technicians can grow A. salina in the laboratory without special equipment. It requires a shorter exposure period and a smaller test volume, as well as offering the advantage of being able to use a high number of organisms, which is useful for statistical evaluation [9]. In general, in these toxicological models, the degree of damage is evaluated after chronic or acute exposure to the substances. Acute tests quantify the concentration of the compound in water that results in mortality for half of the population during a certain period of exposure (LC50) [10]. Chronic tests estimate the mean effective concentration that affects test organisms (usually Daphnia) after a specific period of exposure (EC50) [11]. Nevertheless, additional tests are necessary to complement such studies and record the changes in specific biochemical markers during exposure to different doses, including concentrations below the LC50. These markers may be enzymes that usually protect the cells by catalyzing the conversion of xenobiotic compounds into water or other substances less harmful to the organism. Examples of these enzymes are those that participate in protection against oxidative stress and cell injury, and enzymes facilitating neural activity and nervous system processes, such as glutathione-S-transferase (GST), glutathione peroxidase (GPx), acetylcholinesterase (AChE), lactate dehydrogenase (LDH), and others. Biomonitoring the enzymatic activity therefore can help in characterizing the toxic profile of emerging contaminants [12].

The city of Prague is the capital of and the biggest city in the Czech Republic, also called Czechia. The Vltava river bisects the city, whose population is about 1.2 million people, while the metropolitan area is home to an estimated 2.6 million people [13]. Information on the occurrence of ECs in Prague is scarce or unpublished. However, the surveys conducted by Kozisek et al. [14] and Rozman et al. [15] revealed the existence of these micropollutants in some Czech surface waters, groundwater, and in WWTPs' discharge. The present work studied the occurrence of 46 emerging contaminants from the PPCPs group in the secondary effluent of the WWTP of Prague. We carried out toxicity tests in A. salina nauplii for furosemide, hydrochlorothiazide, and tramadol. These three ECs were present in such effluent and, to the best of our knowledge, do not have toxicological information in this biological model. Furosemide and hydrochlorothiazide are known diuretic pharmaceuticals used to treat high blood pressure and swelling because of fluid build-up [16,17]. Tramadol is a common opioid analgesic known for its potency [18]. Toxicity tests were based mainly on the determination of the LC50 at different exposure times and temperatures, along with determining changes in GST, GPx, AChE, and LDH enzymatic activities when we exposed organisms to lower doses (LC25) of each contaminant at the same temperature and time conditions. The findings presented here are relevant for receiving freshwater bodies, as A. salina is a common food source for fish and marine species in aquaculture [11]. 
These species tend to inhabit coastal and shallow saline water areas, which in turn tend to be close to agricultural areas. The toxicity profile presented here gives an indication of acute toxicity when exposed to these emerging contaminants, as well as the effects of sublethal concentration exposure. These indicators are essential in this specific species because of its capacity of tissue bioaccumulation [19] that could reach the aquatic trophic chain, A. salina being one of the first species in it $[11,19]$.

\section{Materials and Methods}

\subsection{Study Site and Sampling}

Secondary effluent samples were taken from the secondary clarifier (discharge channel) of the WWTP in Prague. It was built on Císařský Island during the 1960s and has undergone many reconstructions and technological upgrades since then. At the time of this study (2016), the WWTP had a capacity of 1.6 million PE (people equivalent) in their existing water line. Currently, it has a new water line that operates at half of the previous capacity (0.8 million PE). The inflow is mainly municipal, and the effluent is usually discharged into natural water bodies, mainly the Vltava River. However, the city is considering reusing it for irrigation of recreational areas.

Water samples were collected using a grab sample method, plastic clean collectors, and 1-L bottles. Sampling campaigns were carried out in April and August, which correspond roughly to the beginning and end of the rainy season in Prague, to verify the consistency of the contaminant concentrations. After sampling, $60 \mathrm{~mL}$ of the raw secondary effluent was stored in sterile dark glass flasks at $-20^{\circ} \mathrm{C}$ (inclined position). Nutrient contents (ammonia, nitrate, nitrite, and phosphate) were determined in our laboratory at UCT Prague according to Czech Standard Methods [20].

\subsection{UHPLC-MS/MS Analysis}

Concentrations of 46 emerging contaminants, mainly PPCPs, were determined by an external laboratory (State Enterprise Povodí Vltavy Plzen). The work of Povodí Vltavy in analyzing and tracking water quality in the Czech Republic is remarkable. They also follow strict protocols; for this study, all analyses were performed according to US EPA Method 1694 [21] for quality assurance. The micropollutants analyzed were already studied by this laboratory in private research (unpublished data), establishing their presence in trace concentrations in the Vltava River in the Czech Republic.

During pretreatment, samples were centrifuged at $3500 \mathrm{rpm}$ for $10 \mathrm{~min}$ (Labnet ${ }^{\circledR}$ Prism R, Edison, NJ, USA), the $\mathrm{pH}$ was adjusted with acetic acid, and a subsequent addition of an internal standard (ISTD) was performed. The analysis was carried out in an ultra-high-performance liquid chromatography system (UHPLC-MS/MS). An Agilent 1290 Infinity Liquid Chromatograph (LC) tandem with 6495 Triple Quadrupole Mass Spectrophotometer (MS/MS) was used in electrospray ionization mode according to EPA Method 1694: Pharmaceuticals and Personal Care Products in Water, Soil, Sediment, and Biosolids by HPLC-MS/MS [21]. Contaminants determination was performed by gradient elution of direct sample injection $(50 \mu \mathrm{L}$ injection volume) using a Waters $X$-bridge column $(\mathrm{C} 18,100 \times 4.6 \mathrm{~mm}, 3.5 \mu \mathrm{m})$ and methanol/water mobile phase (with the addition of $0.02 \%$ acetic acid and $5 \mathrm{mM}$ of ammonium fluoride) at a flow rate of $0.5 \mathrm{~mL} / \mathrm{min}$.

\subsection{Experimental Design}

The ECs selected in this study to determine the LC50 values, and their impact on enzymatic activity in A. salina were those for which no previous data were reported for this crustacean. For enzymatic activity, LC25 values were chosen for each experimental condition (values obtained from the regression data used for LC50 curves) because the organisms needed to be alive to avoid interference due to cellular decay. $3 \times 2 \times 2$ factor design $(\mathrm{EC} \times$ temperature $\times$ exposure time) was used for LC50 and enzymatic activity studies. 


\subsection{Artemia Growth Conditions}

A. salina was purchased as canned cysts (Biogrow Proaqua ${ }^{\circledR}$, Mazatlán Sinaloa, Mexico). A pretreatment for decapsulation was first applied to the cysts: $7.6 \mathrm{~mL}$ of commercial chlorine (bleach) combined with $7.6 \mathrm{~mL}$ of distilled water and $150 \mathrm{mg}$ of $\mathrm{NaOH}$. One gram of cysts was mixed in this solution and stirred continuously for 7 to $10 \mathrm{~min}$. Later, the mix was diluted with tap water and filtered. Filtered cysts were then placed in a glass container with marine water (Instant Ocean ${ }^{\circledR}$ $29.9 \mathrm{mg} / \mathrm{L}$ and distilled water) under continuous aeration for $24 \mathrm{~h}$ at a constant temperature of $28^{\circ} \mathrm{C}$. Since nauplii are attracted to light, a lamp was placed on one side of the container to concentrate them.

\subsection{Toxicological Tests}

Chemical contaminants (analytical grade) were supplied by Sigma-Aldrich ${ }^{\circledR}$ (St. Louis, MO, USA). These were dissolved in milli- $\mathrm{Q}$ water (tramadol) or methanol (furosemide and hydrochlorothiazide). The different concentrations of each compound were prepared using marine water in order to maintain the same salinity across treatments. Toxicity tests were performed in Artemia nauplii at two temperatures: room temperature $\left(20.5\right.$ to $\left.23.5^{\circ} \mathrm{C}\right)$ and $28^{\circ} \mathrm{C}$, and two exposition times: 24 and $48 \mathrm{~h}$. All nauplii were kept fasting during the total length of the bioassays. Experiments were performed in 96-microwell plates: first adding $20 \mu \mathrm{L}$ of marine water containing 10 nauplii and then $230 \mu \mathrm{L}$ of each contaminant dilution to the well $(250 \mu \mathrm{L}$ total working volume). Negative and positive controls containing marine water or potassium dichromate, respectively, were included in all the experiments. Each compound was evaluated by triplicate for each condition, and after 24 or $48 \mathrm{~h}$ the survival rate was recorded. LC50 values were calculated using Microsoft Excel ${ }^{\circledR}$ software to obtain the best-fit linear regression for each bioassay.

\subsection{Enzymatic Activity}

LC25 of furosemide, hydrochlorothiazide, and tramadol were tested at room temperature and $28^{\circ} \mathrm{C}$ during 24 and $48 \mathrm{~h}$. Total of $100 \mathrm{mg}$ of $A$. salina biomass from each assay was resuspended into $1 \mathrm{~mL}$ of phosphate buffer. A $50 \mathrm{mM}$ phosphate buffer at $\mathrm{pH} 7$ was employed for LDH and AChE assays, and $50 \mathrm{mM}$ phosphate buffer with $5 \mathrm{mM}$ of EDTA buffer at pH 7.2 for GPx and GST. Resuspended samples were sonicated in a Bransonic ${ }^{\circledR}$ 5510R-DTH ultrasonic cleaner (Bransonic ${ }^{\circledR}$, Danbury, CT, USA) for $10 \mathrm{~min}$. Subsequently, these were centrifuged for $10 \mathrm{~min}$ at $3500 \mathrm{rpm}$ at $4{ }^{\circ} \mathrm{C}$ (Labnet ${ }^{\circledR}$ Prism $\mathrm{R}$, Edison, NJ, USA). Supernatant was recovered and $100 \mu \mathrm{L}$ samples were transferred to $600 \mu \mathrm{L}$ Eppendorf tubes and used to perform the enzymatic analysis. GPx and LDH were assayed using kits and protocols provided by Cayman chemical ${ }^{\circledR}$ (Ann Arbor, MI, USA) and reactions were measured quantifying the absorbance at 340 and $490 \mathrm{~nm}$, respectively. A continuous spectrophotometric rate determination method described by Habig et al. [22] was used for GST assay, employing 1-chloro-2, 4-dinitrobenzene as substrate and measuring the absorbance at $340 \mathrm{~nm}$. AChE activity was measured photometrically at $410 \mathrm{~nm}$ using the colorimetric Assay Kit ab138871 from $\mathrm{ABCAM}^{\circledR}$ (Cambridge, UK). All enzymatic activities were normalized against protein content measured by Bradford method: $50 \mu \mathrm{L}$ of the supernatant of each assay extract was mixed with $200 \mu \mathrm{L}$ of Bradford reagent (B6916-500ML Sigma-Aldrich ${ }^{\circledR}$, St. Louis, MO, USA) and incubated for 5 min before reading the absorbance at $595 \mathrm{~nm}$ wavelength.

\subsection{Statistical Analysis}

Three-way ANOVA and Tukey's test at the significant level of $\mathrm{P} \leq 0.05$ were used to evaluate the significant differences of LC50 and enzymatic activity values concerning the different variables tested (emerging contaminant, exposure time, and temperature conditions). If significant differences for the different conditions evaluated were observed, a one-way analysis of variance and Tukey's test (for separation of means) were carried out to find a significant difference in the LC50 mean concentration and enzymatic activities concerning the different contaminants under all different conditions evaluated. All statistical analyses were executed using SPSS ${ }^{\circledR}$ version 22 (Chicago, IL, USA) software tool. 


\section{Results and Discussion}

\subsection{Effluent Chemical Characterization}

Out of the 46 compounds tested in the secondary effluent samples from Prague WWTP, only 37 were present (Table 1) and nine were not found or not possible to quantify under the analytical conditions used in this study. The contaminants not detected are mainly pharmaceuticals: penicillin G, sulfamerazine, sulfamethazine, gemfibrozil, warfarin, paracetamol, roxithromycin, carbamazepine 10,11-dihydroxy, and ibuprofen-carboxy. There are no previous assessments about emerging contamination in this specific effluent. However, the survey performed by Rozman et al. [15] in Horní Berkovice, a town situated around $30 \mathrm{~km}$ north of Prague, revealed the existence of different drugs (e.g., carbamazepine, caffeine, metoprolol, sulfapyridine, hydrochlorothiazide, gabapentin, tramadol, clarithromycin, etc.) in the sewage system, including wastewater from a local psychiatric hospital, and in the groundwater saturated zone. Also, Kozisek et al. [14] identified human pharmaceuticals in drinking water facilities in the Czech Republic that employed surface water as inflow. Carbamazepine, ibuprofen, naproxen, and diclofenac were the micropollutants reported, showing concentrations lower (0.5-20.7 ng/L) than those observed in the present study.

In the first sampling campaign in April 2016, average concentrations for two contrast agents (iopromide and iohexol) and the anticonvulsant drug gabapentin were the highest observed (4800, 5700 and $7200 \mathrm{ng} / \mathrm{L}$ respectively). These contaminant levels decreased considerably in the second sampling, mainly for iopromide and iohexol to 63 and $150 \mathrm{ng} / \mathrm{L}$. In a survey conducted by Loos et al. [23] sampling many WWTP effluents across Europe, the average concentration found for iopromide was $2700 \mathrm{ng} / \mathrm{L}$ and $158 \mathrm{ng} / \mathrm{L}$ for iohexol. Concentrations present in the WWTP of Prague were indeed much higher than the continental average and, in the case of iohexol, very close to the maximum concentration reported in that same study (7700 ng/L). However, for iopromide, the continental maximum is greatly above (150,000 ng/L) our findings in Prague. Specifically, in the Czech Republic, Rozman et al. [15] detected iohexol in sewage at a concentration of $430 \mathrm{ng} / \mathrm{L}$ that was reduced to only $19 \mathrm{ng} / \mathrm{L}$ after undergoing conventional wastewater treatment. It is difficult to state the exact reason why the concentrations found here are particularly high and then notably decrease; however, the presence of some industries and hospitals may have had an influence. A chemical manufacturer, Interpharma Praha a.s., is located on the outskirts of Prague, and iohexol and iopromide are among their synthesized products. Although the company counts with its own WWTP, the effluent gets discharged into the urban sewer system, so fluctuations in the concentrations of these chemicals impact the quality of the municipal WWTP discharge directly. Additionally, the hospitals sewage goes to the public sewer system; only wastewater from infectious pavilions are obliged to have their own separated treatment. It is evident that all kinds of contrast media and pharmaceuticals used in instrumental medical examinations can get into public sewers, which could also explain the high fluctuations in iopromide, iohexol, and gabapentin. Nevertheless, according to toxicological tests on $A$. salina and fish, these concentrations by themselves may not be a concern for aquatic wildlife (LC50 values for gabapentin and iopromide are 8550 and $>962 \mathrm{mg} / \mathrm{L}$ respectively). However, specific reports on their combined effects with other compounds are still scarce $[24,25]$. Other visible discrepancies in concentration from one sampling campaign to another can be seen in the antibiotic clarithromycin (1300-430 ng/L), a drug also found in $82 \%$ of sewage samples taken in Czech Republic rural areas, whose concentration varied from under the limit of detection (LOD) (<10 ng/L) to $2500 \mathrm{ng} / \mathrm{L}$ [26]. These results suggest that clarithromycin is a ubiquitous substance in wastewater in the Czech Republic, and the concentrations vary greatly. The rest of the micropollutants exhibited very stable concentrations over time, such as the caffeine (220-270 ng/L), carbamazepine (460-500 ng/L), diclofenac (1800-1900 ng/L), furosemide (1200-1300 ng/L), metoprolol (1520-1530 ng/L), naproxen (530-560 ng/L), ranitidine (160-190 ng/L), sulfapyridine (240-270 ng/L), and tramadol (810-870 ng/L). The pharmaceuticals with the lowest concentrations quantified in this sampling period were bezafibrate, oxcarbazepine, and triclocarban (11, 15, and $17 \mathrm{ng} / \mathrm{L}$ respectively), and chloramphenicol was below the LOD. All these contaminants did not exceed the maximum concentration reported in other effluents from WWTPs worldwide, ranging from $262 \mathrm{ng} / \mathrm{L}$ to $79.86 \mu \mathrm{g} / \mathrm{L}$ [27-29]. 
As for the second monitoring period, gabapentin also had the highest effluent concentration (2200 ng/L), and the antiepileptic oxcarbazepine, chloramphenicol, and erythromycin the lowest ones $(18,21$, and $16 \mathrm{ng} / \mathrm{L}$ respectively). The other antibiotics investigated, azithromycin, clarithromycin, sulfamethoxazole, and trimethoprim, were detected, ranging from 360 to $1300 \mathrm{ng} / \mathrm{L}$. Atenolol, iopamidol, ketoprofeno, and the antidepressants sertraline and venlafaxine displayed concentrations $<0.5 \mu \mathrm{g} / \mathrm{L}$ in all effluent samples. Other micropollutants were found below the LOD during the second sampling: bezafibrate, carbamazepine-2-hydroxy, sulfanilamide, triclocarban, and triclosan. Although these latter have shown the most toxic effects on A. salina at $24 \mathrm{~h}$ exposition (Table 1 ), the concentrations detected in this study are much lower than the LC50 reported $(17.8$ and $171.1 \mu \mathrm{g} / \mathrm{L}$ respectively). As for the pharmaceuticals previously reported in the Czech Republic [15], their concentrations observed here were generally much higher than those in Horní Berkovice WWTP output, except carbamazepine (500 vs. $2725 \mathrm{ng} / \mathrm{L}$ ), gabapentin (7200 vs. $14050 \mathrm{ng} / \mathrm{L}$ ), sulfamethoxazole (530 vs. $630 \mathrm{ng} / \mathrm{L}$ ), and sulfapyridine ( 270 vs. $534 \mathrm{ng} / \mathrm{L}$ ).

According to the last environmental implementation review of the Czech Republic in 2019, the most significant pressures on rivers, in terms of the proportion of the affected surface of water bodies, come from anthropogenic sources ( $70 \%$ of surface water bodies), urban wastewater (38\%), diffuse pollution from agriculture (22\%), and diffuse atmospheric deposition $(22 \%)$; chemical pollution $(48 \%)$ and nutrient pollution $(41 \%)$ had the most significant impact on surface water. Even though all wastewater within this country is collected, barely $90.5 \%$ undergoes secondary treatment and only $62.7 \%$ more advanced treatment processes, which may explain why some emerging contaminants persist after primary or secondary waste treatment process [30]. In the present study, some emerging contaminants such as antibiotics, anti-inflammatories, diuretics, antiepileptics, and blood pressure medications were detected in the local WWTP effluents, which agreed with previous reports on this country $[14,15,31]$. Furthermore, our study sets a precedent in the capital of the Czech Republic and lines up with the release of the recommendation paper to introduce specific measures to address Contaminants of Emerging Concern in the Urban Waste Water Treatment Directive [32]. As for resource water recovery, the results obtained here will be used, among others, for research on irrigation using Prague's WWTP effluent, as part of the EU scheme Horizon 2020.

It is essential to point out that although water sample collection was carried out in 2016 and the toxicology profiling in 2019, this falls within the publication time range of other studies carried out in the Czech Republic, for the quantification of ECs in water sources that required at least two or three years to be published $[15,26]$. Even so, our future research plans include a new sampling campaign to update the levels of ECs in the WWTP effluent of the city of Prague and compare the behavior of these micropollutants over time, and to increase the number of compounds evaluated using Artemia salina and other study model organisms. The new study will possibly include a high-resolution effect-directed analysis (EDA) [6] to optimize analyses of many samples and help identify endocrine disruptors.

Regarding nutrient analyses, the average content in the raw secondary effluent was $1.6 \mathrm{mg} / \mathrm{L}$ $\mathrm{NH}_{4}{ }^{+}, 0.1 \mathrm{mg} / \mathrm{L} \mathrm{NO}_{2}{ }^{-}, 3.9 \mathrm{mg} / \mathrm{L} \mathrm{NO}_{3}{ }^{-}$, and $0.08 \mathrm{mg} / \mathrm{L} \mathrm{PO}_{4}{ }^{3-}$. These concentrations are below the standard limits of acceptable wastewater pollution for discharge into water bodies in the Czech Republic [33], which indicate maximum concentrations for total nitrogen and phosphorous of 10 and $1 \mathrm{mg} / \mathrm{L}$ respectively; therefore, in terms of nutrient concentration, the depuration process of the WWTP of Prague is performing adequately. However, this municipal WWTP was not designed to treat ECs, and there are no current regulations that apply limits for these substances. Although the objective of this study was not to evaluate treatment options for emerging contaminants, there are new technologies [26,34] that could be used in the effluent of this WWTP, according to the characterization and toxicological assessment that we have carried out about these micropollutants. 
Table 1. Emerging contaminants concentration detected in the secondary effluent of the Prague wastewater treatment plants (WWTP) and available toxicological information in Artemia salina.

\begin{tabular}{|c|c|c|c|c|}
\hline Emerging Contaminant & $\begin{array}{l}\text { Concentration Sampling } \\
\text { April } 2016(\mathrm{ng} / \mathrm{L})\end{array}$ & $\begin{array}{l}\text { Concentration Sampling } \\
\text { August } 2016(\mathrm{ng} / \mathrm{L})\end{array}$ & $\begin{array}{l}\text { A. salina } \\
\text { Ecotoxicity }\end{array}$ & Dose \\
\hline Atenolol & 290 & 190 & yes & $\begin{array}{c}>100 \mathrm{mg} / \mathrm{L}(\mathrm{LC} 5048 \mathrm{~h})[24] \\
<0.125 \mathrm{mg} / \mathrm{mL}(\mathrm{LC} 5048 \mathrm{~h})[35]\end{array}$ \\
\hline Azithromycin & 1300 & 1200 & yes & $\begin{array}{c}>100 \mathrm{mg} / \mathrm{L}(\mathrm{LC} 5048 \mathrm{~h})[24] \\
110.316 \mu \mathrm{g} / \mathrm{mL}(\mathrm{LC} 5024 \mathrm{~h})[8]\end{array}$ \\
\hline Bezafibrate & 11 & $<10$ & no & \\
\hline Caffeine & 220 & 270 & yes & $\begin{array}{l}0.5 \mathrm{mg} / \mathrm{mL} \text { (LC90 } 48 \mathrm{~h})[35] \\
306 \mu \mathrm{g} / \mathrm{mL}(\mathrm{LC} 5024 \mathrm{~h})[36]\end{array}$ \\
\hline Carbamazepine & 460 & 500 & yes & $>100 \mathrm{mg} / \mathrm{L}(\mathrm{LC} 5048 \mathrm{~h})[24]$ \\
\hline Carbamazepine 10,11-dihydro-10-hydroxy & 120 & 67 & no & \\
\hline Carbamazepine 10,11-epoxide & 39 & 42 & no & \\
\hline Carbamazepine-2-hydroxy & 77 & $<10$ & no & \\
\hline Chloramphenicol & $<20$ & 21 & yes & $>100$ mg/L (LC50 48 h) [24] \\
\hline Clarithromycin & 1300 & 430 & yes & $>100$ mg/L (LC50 48 h) [24] \\
\hline Diclofenac & 1900 & 1800 & yes & $\begin{array}{c}>100 \mathrm{mg} / \mathrm{L}(\mathrm{LC} 5048 \mathrm{~h}) \text { [24] } \\
>20 \mathrm{mg} / \mathrm{L}(\mathrm{LC} 1024 \mathrm{~h}, 48 \mathrm{~h})[37]\end{array}$ \\
\hline Diclofenac-4'-hydroxy & 720 & 600 & no & \\
\hline Erythromycin & 78 & 16 & yes & $\begin{array}{c}>100 \mathrm{mg} / \mathrm{L}(\mathrm{LC} 10120 \mathrm{~h})[38] \\
0.5 \mathrm{mg} / \mathrm{mL}(\mathrm{LC} 9048 \mathrm{~h})[35]\end{array}$ \\
\hline Furosemide & 1300 & 1200 & no & \\
\hline Gabapentin & 7200 & 2200 & yes & $>100$ mg/L (LC50 48 h) [24] \\
\hline Hydrochlorothiazide & 2700 & 1900 & no & \\
\hline Ibuprofen & 170 & 450 & yes & $373.526 \mu \mathrm{g} / \mathrm{mL}(\mathrm{LC} 5024 \mathrm{~h})[8]$ \\
\hline Ibuprofen-2-hydroxy & 1800 & 530 & no & \\
\hline Iohexol & 5700 & 150 & no & \\
\hline Iopamidol & 470 & 190 & no & \\
\hline Iopromide & 4800 & 63 & no & \\
\hline Ketoprofen & 260 & 180 & yes & 13.24 mg/L (LC50 48 h) [24] \\
\hline Metoprolol & 1520 & 1530 & yes & $>100$ mg/L (LC50 48 h) [24] \\
\hline Naproxene & 560 & 530 & yes & $>100$ mg/L (LC50 48 h) [24] \\
\hline Naproxene-O-desmethyl & 170 & 240 & no & \\
\hline Oxcarbazepine & 15 & 18 & no & \\
\hline
\end{tabular}


Table 1. Cont.

\begin{tabular}{|c|c|c|c|c|}
\hline Emerging Contaminant & $\begin{array}{c}\text { Concentration Sampling } \\
\text { April } 2016(\mathrm{ng} / \mathrm{L})\end{array}$ & $\begin{array}{l}\text { Concentration Sampling } \\
\text { August } 2016(\mathrm{ng} / \mathrm{L})\end{array}$ & $\begin{array}{l}\text { A. salina } \\
\text { Ecotoxicity }\end{array}$ & Dose \\
\hline Ranitidine & 160 & 190 & no & \\
\hline Saccharine & 2000 & 1800 & no & \\
\hline Sertraline & 35 & 25 & yes & $4.08 \mathrm{mg} / \mathrm{L}(\mathrm{LC} 5048 \mathrm{~h}$ ) [24] \\
\hline Sulfamethoxazole & 360 & 530 & yes & $>100 \mathrm{mg} / \mathrm{L}(\mathrm{LC} 5048 \mathrm{~h})$ \\
\hline Sulfanilamide & 75 & $<50$ & no & \\
\hline Sulfapyridine & 270 & 240 & no & \\
\hline Tramadol & 810 & 870 & no & \\
\hline Triclocarban & 17 & $<10$ & yes & $17.8 \mu \mathrm{g} / \mathrm{L}$ (LC50 24 h) [39] \\
\hline Triclosan & 49 & $<20$ & yes & $171.1 \mu \mathrm{g} / \mathrm{L}(\mathrm{LC} 5024 \mathrm{~h}$ ) [39] \\
\hline Trimetoprim & 500 & 370 & yes & $>100 \mathrm{mg} / \mathrm{L}(\mathrm{LC} 5048 \mathrm{~h})$ \\
\hline Venlafaxine & 340 & 320 & yes & $>100 \mathrm{mg} / \mathrm{L}(\mathrm{LC} 5048 \mathrm{~h})$ \\
\hline
\end{tabular}

LC10 (lethal concentration 10), LC50 (lethal concentration 50), LC90 (lethal concentration 90), h (hours). 


\subsection{Acute Toxicity Tests on Artemia Salina}

As depicted in Table 1, the mortality effects on aquatic organisms such as A. salina have been reported for many ECs identified in the secondary effluent from the Prague WWTP. Reported LC50 values were as low as $17 \mu \mathrm{g} / \mathrm{L}$ after 24-h exposure (triclocarban) [39] and greater than $100 \mathrm{mg} / \mathrm{L}$, with caffeine $(306 \mathrm{mg} / \mathrm{L})$, the least toxic among the contaminants here reviewed [36]. Meanwhile, other compounds such as furosemide, hydrochlorothiazide, and tramadol have not been investigated in terms of acute toxicity in this model organism, thus, their selection for the present toxicological assessment. The rest of the substances lacking ecotoxicological profiling will be assayed in future studies. Besides being one of the most widely used indicator organisms for LC50, A. salina has been previously employed by our research group to evaluate other emerging micropollutants, including their degradation products and biological treatment [40].

It has been reported that Artemia species tolerate a wide range of temperatures and salinities [41,42]; although their optimal temperature for growth and survival range lies between 20 and $28^{\circ} \mathrm{C}$ [41,43]. Under the temperature conditions evaluated here $\left(28^{\circ} \mathrm{C}\right.$ and room temperature ranging from 20.3 to $24.4^{\circ} \mathrm{C}$ ), the survival rate for the control treatment ranged in all replicates from 93 to $98 \%$ among treatments (data not shown), indicating that the mortality values obtained were due to the experimental conditions. Moreover, potassium dichromate has been used as a positive control in other acute toxicity tests in A. salina [43]. The LC50 estimated for $\mathrm{K}_{2} \mathrm{Cr}_{2} \mathrm{O}_{7}$ was significantly influenced $(p<0.01)$ by temperature conditions ( 40.8 and $20.3 \mathrm{mg} / \mathrm{L}$ at room temperature and $28{ }^{\circ} \mathrm{C}$ respectively) and for exposure time ( 40.8 and $9.1 \mathrm{mg} / \mathrm{L}$ or 20.3 and $4.7 \mathrm{mg} / \mathrm{L}$ after 24 or $48 \mathrm{~h}$ respectively). A significant interaction $(p<0.01)$ was also found between these test factors (Figure 1). This reduction in LC50 values because of increasing warming conditions and exposure time agreed with previous results obtained in crustaceans, such as brine shrimp $\left(25\right.$ to $\left.30^{\circ} \mathrm{C}\right)$ and Daphnia magna $\left(21-28^{\circ} \mathrm{C}\right)$ but not for Brachionus plicatilis, showing that the magnitude of its toxicity is also species-specific [44].

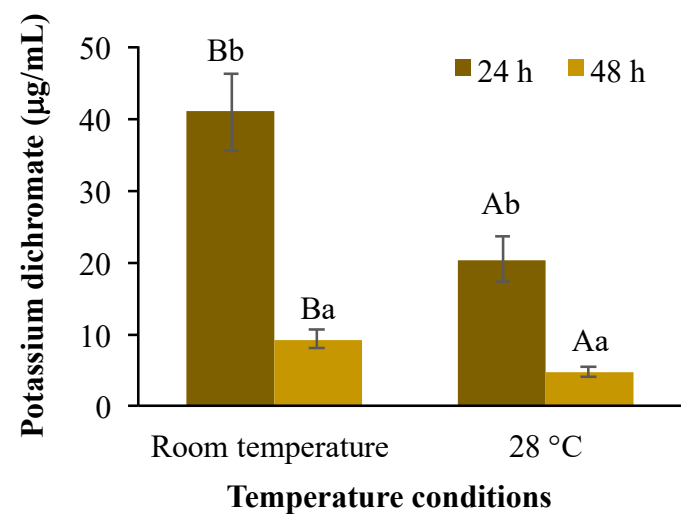

Figure 1. Lethal concentration 50 (LC50) in A. salina after exposure to potassium dichromate during 24 and $48 \mathrm{~h}$ at room temperature and $28^{\circ} \mathrm{C}$. Columns with the same capital letter (A and B) are not significantly different $(\alpha=0.05)$ between temperature conditions; means with the same lowercase letter ( $a$ and $b$ ) are not significantly different $(\alpha=0.05)$ with respect to exposition time. Values are mean \pm SEM of all treatments for each condition $(n=20)$.

Acute toxicity results on $A$. salina after exposure to the different ECs evaluated are shown in Figure 2. Furosemide was more toxic than hydrochlorothiazide and tramadol, since its LC50 concentrations were the lowest. LC50 for furosemide was also almost independent of the temperature and exposure time ( $225 \mathrm{up}$ to $273 \mathrm{mg} / \mathrm{L}$ ). Its LC50 values were even higher than those reported in other aquatic species, which ranged from 5.9 to $137 \mathrm{mg} / \mathrm{L}$ for algae and fish, respectively [45,46], while in the cnidarian Hydra vulgaris, the luminescent bacterium $V$. fischeri and the rotifer B. calyciflorus the furosemide did not have any toxic effect [45,47]. LC50 values for hydrochlorothiazide varied according to temperature conditions at $24 \mathrm{~h}$ exposition ( $>3000$ and $1564 \mathrm{mg} / \mathrm{L}$ for $28^{\circ} \mathrm{C}$ and room temperature), 
but after 48-h exposure the LC50 estimates were similar (918 and $957 \mathrm{mg} / \mathrm{L}$ for room temperature and $28^{\circ} \mathrm{C}$, respectively). For tramadol, LC50 toxicity values were higher at room temperature ( $>14,000$ and $1748 \mathrm{mg} / \mathrm{L}$ for 24 and $48 \mathrm{~h}$ ) than $28^{\circ} \mathrm{C}$ ( 4419 and $838 \mathrm{mg} / \mathrm{L}$ after 24 and $28 \mathrm{~h}$, respectively). Although tramadol showed the least toxic effects in terms of killing half of the population, requiring very high concentrations to do so, the effects of this contaminant could be seen almost immediately on A. salina. The organisms started swimming very slowly, almost like trembling, rather than displacing from one side to another as they commonly move (data not shown). This effect could have ecological consequences, like affecting the vulnerability to predators. No available information about the effect of tramadol and hydrochlorothiazide on aquatic organisms was found to compare with the results obtained here.
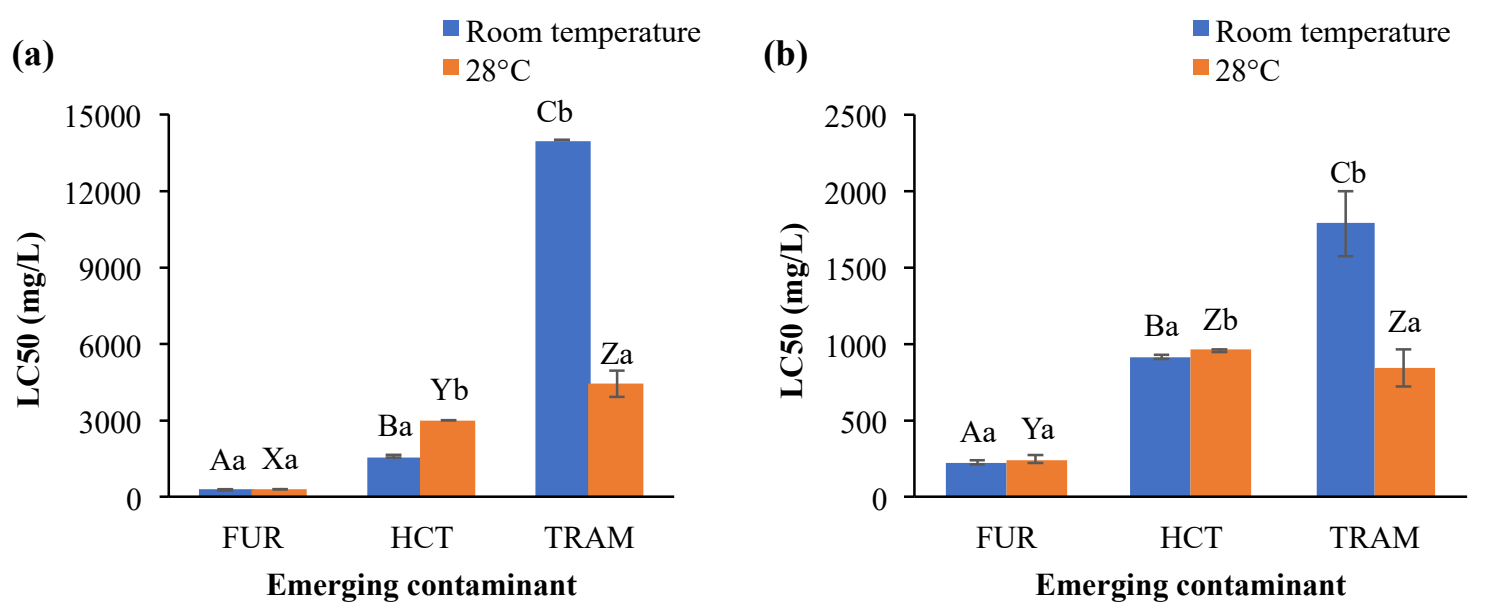

Figure 2. Lethal concentration 50 (LC50) in A. salina after exposure to furosemide (FUR), hydrochlorothiazide (HCT), and tramadol (TRAM) during (a) 24 and (b) $48 \mathrm{~h}$ at room temperature and $28^{\circ} \mathrm{C}$. Columns with the same capital letter (A, B, C, X, Y, and Z) are not significantly different $(\alpha=0.05)$ among the tested compounds; means with the same lowercase letter $(\mathbf{a}, \mathbf{b})$ are not significantly different $(\alpha=0.05)$ with respect to temperature conditions. Values are mean \pm SEM of all treatments for each condition $(n=3)$.

Bioaccumulation, elimination rate, and toxicity of the chemical contaminants on aquatic organisms are also influenced by environmental conditions (temperature, salinity, $\mathrm{pH}$, etc.). Focusing on temperature, Martins et al. [48] reported that chronic toxicity of the antibiotic florfenicol in Daphnia magna increased as temperature rose (LC50 $=7.6$ and $1.9 \mathrm{mg} / \mathrm{L}$ at 20 and $25^{\circ} \mathrm{C}$ respectively). Li et al. [49] concluded that the toxicity of copper, DDT, triphenyltin, and pyrithione to the medaka fish Oryzias melastigma larvae, the copepod Tigriopus japonicus, and the rotifer Brachionus koreanus were temperature-dependent and the LC50 for all four chemicals decreased as the temperature increases. The same effect was observed in other aquatic species when they were exposed to chlorpyrifos and phenol [50]. Meanwhile, the increase in temperature impacted the bioaccumulation and elimination of dechloranes $(602,603$, and 604) in R. philippinarum (Japanese carpet shell), but also facilitated the elimination of some other substances such as arsenic and tetrabromobisphenol A [51]. The exposure to emerging contaminants at high-temperature conditions also increases the energy costs to aquatic organisms, as well as prompting impaired aerobic energy production because of a progressive mismatch between the oxygen demand and oxygen supply, resulting in mitochondrial dysfunction [52], cellular antioxidant systems depletion and peroxidation of the membrane lipids [53]. In the present study, LC50 values for hydrochlorothiazide were higher at $28^{\circ} \mathrm{C}$ than at room temperature (Figure 2a); in contrast to tramadol (Figure 2a,b), where LC50 for A. salina was reduced as temperature and exposure time increased. These results indicated that toxicity induced by these micropollutants is clearly affected by environmental conditions such as temperature and exposure time. The statistical analysis supported that overall LC50 toxicity values were significantly affected by the exposure time, temperature, and 
EC (Table 2). Also, significant interactions $(p<0.001)$ were observed for emerging contaminant $\times$ temperature $(\mathrm{EC} \times \mathrm{T})$, emerging contaminant $\times$ exposure time $(\mathrm{EC} \times \mathrm{ET})$, temperature $\times$ exposure time $(\mathrm{T} \times \mathrm{ET})$, and emerging contaminant $\times$ temperature and exposure time $(\mathrm{EC} \times \mathrm{T} \times \mathrm{ET})$.

Table 2. Probabilities of the three one-way statistical analyses for LC50 and enzymatic activity of glutathione S-transferase (GST), glutathione peroxidase (GPx), lactate dehydrogenase (LDH), and acetylcholinesterase (AChE) at the different experimental conditions evaluated.

\begin{tabular}{cccccc}
\hline Parameter & LC50 & GST & GPx & LDH & AChE \\
\hline EC & $p<0.001$ & $p<0.01$ & $p<0.01$ & $p<0.01$ & $p<0.01$ \\
T & $p<0.001$ & $p<0.01$ & $p<0.01$ & $p<0.01$ & $p<0.01$ \\
ET & $p<0.001$ & $p<0.01$ & $p<0.01$ & $p<0.01$ & $p<0.01$ \\
EC $\times$ T & $p<0.001$ & $p<0.01$ & $p<0.01$ & $p<0.01$ & $p<0.01$ \\
EC $\times$ ET & $p<0.001$ & $p<0.01$ & $p>0.05^{*}$ & $p<0.01$ & $p<0.01$ \\
T $\times$ ET & $p<0.001$ & $p>0.05^{*}$ & $p<0.01$ & $p<0.01$ & $p<0.01$ \\
EC $\times$ T $\times$ ET & $p<0.001$ & $p<0.01$ & $p<0.01$ & $p<0.01$ & $p<0.01$ \\
\hline
\end{tabular}

$\mathrm{EC}=$ emerging contaminant, $\mathrm{T}=$ temperature, $\mathrm{ET}=$ exposure time, ${ }^{*}$ Non-significant interaction.

Physicochemical properties of the emerging contaminant substances, such as water solubility, photodegradation, transformation, degradation, etc., are often related to their toxicity [54]. Tramadol in particular is more soluble in water $\left(1151 \mathrm{mg} / \mathrm{L}\right.$ at $\left.25^{\circ} \mathrm{C}\right)$ [55] than furosemide $\left(73.1 \mathrm{mg} / \mathrm{L}\right.$ at $\left.30{ }^{\circ} \mathrm{C}\right)$ [56] and hydrochlorothiazide $\left(722 \mathrm{mg} / \mathrm{L}\right.$ at $\left.25^{\circ} \mathrm{C}\right)$ [56]. Additionally, chemical degradation by light exposition is different for each compound, e.g., furosemide was quickly degraded (0.5 to $1.5 \mathrm{~h})$ under artificial light or diffused daylight [57], whereas hydrochlorothiazide and tramadol persisted after 5 to $168 \mathrm{~h}$ under irradiation (150 W) at room temperature [58], Hg lamp, or direct sunlight [59]. Our results indicate that furosemide was more toxic than hydrochlorothiazide and tramadol, despite its quick degradation, suggesting its transformation products may be also responsible for the reduction in A. salina survival. Several studies have demonstrated that degradation products were more toxic to aquatic organisms than the original compounds, e.g., prednisone [60] and some derivatives as 2,4-dinitroanisole [61]. The identification and toxicity of the byproducts of each substance tested in the present study need to be further analyzed.

\subsection{Changes on Enzymatic Activity}

Sublethal concentrations (LC25) were estimated for furosemide, hydrochlorothiazide, and tramadol in order to evaluate their impact on A. salina nauplii at cellular and enzymatic level, particularly oxidative enzymes (GST and GPx), neural activity and nervous system (AChE), and cell injury (LDH). In general, enzymatic activity was impacted by the contaminant, that relationship is dependent on the exposure time and temperature (Table 2) with a significant interaction between these experimental conditions, with the exception of temperature $\times$ exposure time $(\mathrm{T} \times \mathrm{ET})$ and $\mathrm{EC} \times$ exposure time $(\mathrm{EC} \times$ ET) that were not significantly different $(>0.05)$ for GST and GPx activities.

\subsubsection{Glutathione S-Transferase}

GST enzyme belongs to phase II of the detoxification process and defense cells against oxidative damage and peroxidative products of DNA and lipids [62]. In A. salina, three or four isoenzymes have been identified depending on the developmental stage [62]. Figure 3 shows the total GST activity in test treatments under different conditions. A significant reduction from 114.5 to $69.7 \mathrm{mU} / \mathrm{mL}$ on GST activity was observed in the control group at warm conditions $\left(28^{\circ} \mathrm{C}\right)$; and as exposure time increased (Figure $3 \mathrm{~b}$ ), this activity was $27 \%$ (room temperature) and $62 \%\left(28^{\circ} \mathrm{C}\right)$ lower. GST activity was, in general, remarkably higher in nauplii exposed during $24 \mathrm{~h}$ to the three compounds (156.7 to $242.4 \mathrm{mU} / \mathrm{mL}$ and 109.7 to $335.4 \mathrm{mU} / \mathrm{mL}$ at room temperature and $28^{\circ} \mathrm{C}$ respectively), with tramadol presenting the highest activity compared to the control. After $48 \mathrm{~h}$ exposure, it was observed that 
GST activity in tramadol treatments was not significantly different at either temperature (160.3 and $174.1 \mathrm{mU} / \mathrm{mL}$ ), but for furosemide, the enzymatic activity decreased in comparison to 24-h exposure (33 to $72 \%)$. Hydrochlorothiazide at room temperature also caused a GST activity reduction $(16.79 \mathrm{mU} / \mathrm{mL})$ after $48 \mathrm{~h}$ of exposure; however, as the temperature rose, enzyme levels reached up to $218.8 \mathrm{mU} / \mathrm{mL}$. As mentioned, the interactions between these test factors were found to be statistically significant $(p<0.01)$, except for temperature and exposure time.
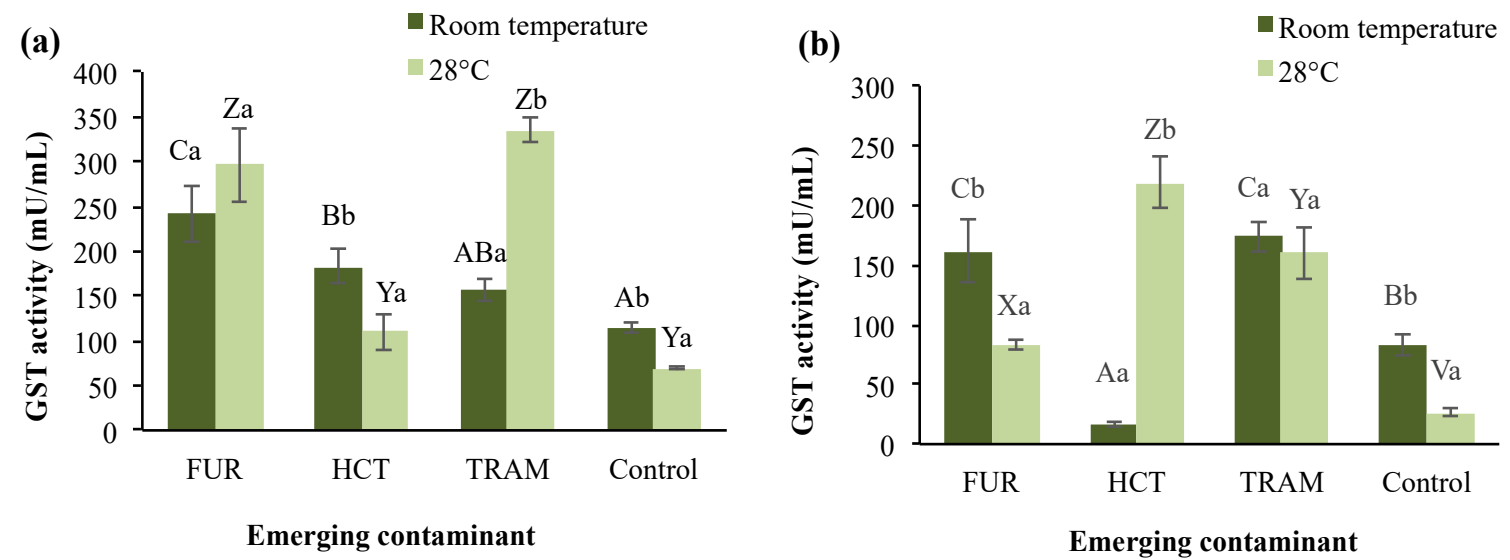

Figure 3. Glutathione S-transferases (GST) activity in A. salina nauplii exposed to furosemide (FUR), hydrochlorothiazide (HCT), tramadol (TRAM) and uncontaminated control during (a) 24 and (b) $48 \mathrm{~h}$ at room temperature and $28{ }^{\circ} \mathrm{C}$. Columns with the same capital letter $(\mathrm{A}, \mathrm{B}, \mathrm{C}, \mathrm{V}, \mathrm{X}, \mathrm{Y}$, and Z) are not significantly different $(\alpha=0.05)$ among tested compounds; means with the same lowercase letter $(\mathbf{a}, \mathbf{b})$ are not significantly different $(\alpha=0.05)$ with respect to the temperature conditions. Values are expressed as mean \pm SEM $(n=3)$.

A significant increase in GST activity has also been reported in A. salina exposed to municipal wastewater effluent [63]. The increasing activity of GST indicates that this enzyme is catalyzing the conjugation of glutathione with xenobiotic substances, which agrees with previous reports on Daphnia after being exposed to propranolol [64]. The variation in GST activity due to the exposure time and temperature conditions indicates that these two factors, plus the nature of the emerging contaminant, determine the environmental impact and the response to oxidative stress of $A$. salina, and most likely other aquatic organisms.

\subsubsection{Glutathione Peroxidase}

GPx is another enzyme involved in the protection of the organism from oxidative damage [65] by acting as a scavenger for hydrogen peroxide [66]. Figure 4 shows GPx activity in $A$. salina nauplii exposed to furosemide, hydrochlorothiazide, and tramadol at different temperatures and exposure times. GPx activity in the control group at 24-h exposure was $43.9 \%$ higher at room temperature than at $28{ }^{\circ} \mathrm{C}$ (36.1 vs. $15.8 \mathrm{mU} / \mathrm{mL}$ ), whereas after $48 \mathrm{~h}$ of exposure, the enzymatic activity tended to remain stable and similar for both temperature conditions (20.6-22.3 mU/mL). The effect of the temperature rise in GPx activity has been reported by Lushchac and Bangyukova [67], where GPx in brain, liver, and muscle in goldfish exposed to $35^{\circ} \mathrm{C}$ decreased by one-third compared to the control after $1 \mathrm{~h}$ of exposure, but was restored after $6 \mathrm{~h}$ and did not change significantly again, which is in accordance with the control behavior in our results at warmer temperature. 


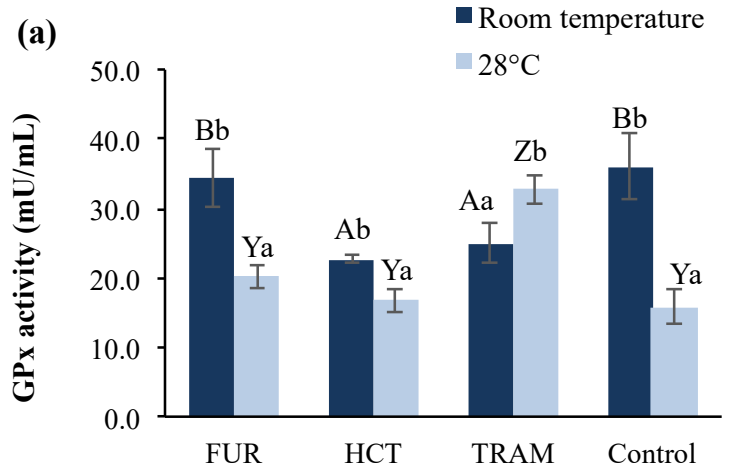

Emerging contaminant

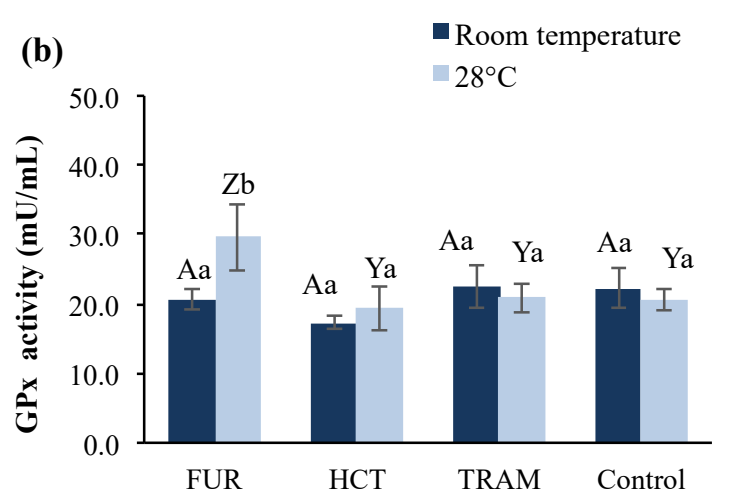

Emerging contaminant

Figure 4. Glutathione peroxidase (GPx) activity in A. salina nauplii exposed to furosemide (FUR), hydrochlorothiazide (HCT), tramadol (TRAM) and uncontaminated control during (a) 24 and (b) $48 \mathrm{~h}$ at room temperature and $28{ }^{\circ} \mathrm{C}$. Columns with the same capital letter (A, B, Y, and Z) are not significantly different $(\alpha=0.05)$ among the tested compounds, and means with the same lowercase letter $(\mathbf{a}, \mathbf{b})$ are not significantly different $(\alpha=0.05)$ with respect to different temperature conditions. Values are expressed as mean $\pm \operatorname{SEM}(n=3)$.

In test treatments, the GPx activity presented a significant reduction (31-37\%) at room temperature after 24-h exposure to hydrochlorothiazide and tramadol in comparison to the control. At $28^{\circ} \mathrm{C}$ the effect of the hydrochlorothiazide was not observed, presenting enzymatic activity $(16.6 \mathrm{mu} / \mathrm{mL})$ almost identical to that of the control group $(15.8 \mathrm{mU} / \mathrm{mL})$. In the presence of furosemide, GPx activity was statistically similar to the control at room temperature and $28^{\circ} \mathrm{C}$ with activities of 34.3 and $20.1 \mathrm{mU} / \mathrm{mL}$ respectively. After 48-h exposure, GPx levels were restored to control values in all test conditions, except for furosemide at $28{ }^{\circ} \mathrm{C}$, where GPx was increased by $43 \%$. It is conspicuous that room temperature was the condition where a significant impact on GPx activity was observed for hydrochlorothiazide and tramadol but not furosemide, which showed a belated effect after $48 \mathrm{~h}$ exposure time, at which the reduction in enzyme activity caused by the other contaminants had disappeared. Nunes et al. [66] previously reported that no significant effect on GPx activities was observed in A. salina after exposure to sodium dodecyl sulfate and diazepam, whereas the exposure to clofibric acid and clofibrate reduced the activity as test concentration increased. Nevertheless, exposure of D. magna to benzoylecgonine (cocaine metabolite) increased the GPx activity by 1.7-fold and raised the swimming activity [68].

Similarly, tramadol enhanced GPx activity in our bioassays at warmer conditions, but it reduced the overall swimming activity of A. salina. Not only the contaminant, but also its metabolites (e.g., cocaine metabolites) are involved in the activation of redox cycles, depletion, and decrease of antioxidant enzymes leading to the overproduction of reactive oxygen species and oxidative stress conditions [68]. For this reason, it would be fascinating to evaluate in future studies the metabolization of tramadol in A. salina and the possible effects of its metabolites (O-desmethyltramadol and $\mathrm{N}$-desmethyltramadol) on survival and enzymatic.

\subsubsection{Lactate Dehydrogenase}

LDH is a ubiquitous enzyme in nearly all living cells, including $A$. salina, that has been used to determine cellular damage caused by the presence of pollutants [69]. Figure 5 shows the LDH activity in brine shrimp exposed to furosemide, hydrochlorothiazide, and tramadol at different temperatures and exposure times. LDH activity in control groups was very similar, independently of the temperature and time of exposure, ranging from 1.1 to $1.5 \mathrm{mU} / \mathrm{mL}$. At 24-h exposure, all the test contaminants increased the LDH activity at room temperature; hydrochlorothiazide and tramadol induced the highest increment to reach 6.9 and $6.4 \mathrm{mU} / \mathrm{mL}$. While at $28^{\circ} \mathrm{C}$ only tramadol and furosemide increased LDH levels by 40 and $60 \%$ respectively. When extending the exposure time ( $48 \mathrm{~h}$; Figure $5 \mathrm{~b}$ ), all LDH 
activities were reduced at levels near to the control group. However, a significant increase in LDH activity (up to $2.6 \mathrm{mU} / \mathrm{mL}$ ) continued to show in nauplii treated with furosemide and tramadol at room temperature. However, at warmer temperatures, there were no changes compared to the rest of the treatments. Higher LHD activity has been observed in aquatic organisms exposed to other contaminants, e.g., tannery wastewater [69] and heavy metals [70]. As the LDH enzyme plays a crucial role in anaerobic metabolism, homeostasis, and gluconeogenesis in many vital tissues [71], changes in LDH activity because of the ECs (especially hydrochlorothiazide, which suppressed LDH activity) may alter $A$. salina homeostasis, contributing to mortality. The correlation between minimal or null LDH activities and death rate of $A$. salina has been documented in other study where it was exposed to food dyes during $48 \mathrm{~h}$ [72].
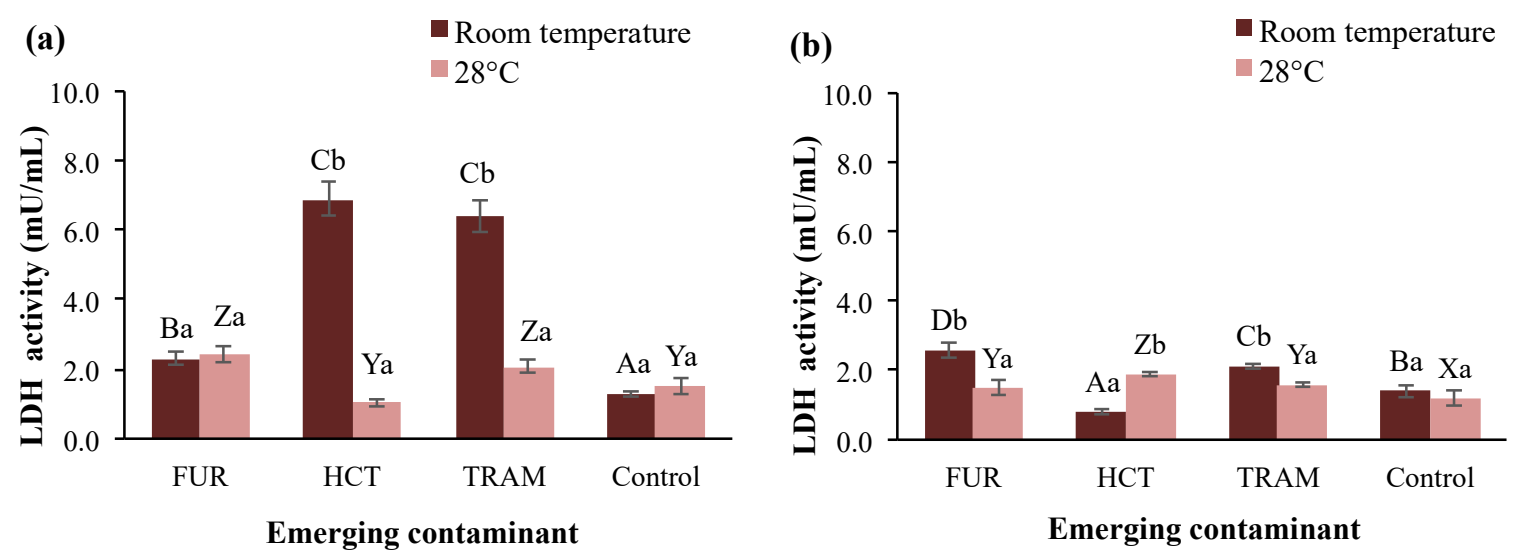

Figure 5. Lactate dehydrogenase (LDH) activity in A. salina nauplii exposed to furosemide (FUR), hydrochlorothiazide (HCT), tramadol (TRAM) and uncontaminated control during (a) 24 and (b) $48 \mathrm{~h}$ at room temperature and $28{ }^{\circ} \mathrm{C}$. Columns with the same capital letter $(\mathrm{A}, \mathrm{B}, \mathrm{C}, \mathrm{D}, \mathrm{X}, \mathrm{Y}$, and Z) are not significantly different $(\alpha=0.05)$ among the tested compounds, and means with the same lowercase letter $(\mathbf{a}, \mathbf{b})$ are not significantly different $(\alpha=0.05)$ with respect to temperature conditions. Values are expressed as mean $\pm \operatorname{SEM}(n=3)$.

\subsubsection{Acetylcholinesterase}

$\mathrm{AChE}$ is a common biomarker for assessing the toxicity of pollutants that affect the nervous system with the potent catalytic activity of hydrolyzing acetylcholine [73], and it plays an essential role in the cholinergic neurotransmission involved in respiration processes and locomotion activities [74]. As shown in Figure 6, $\mathrm{AChE}$ levels in the control group were significantly higher at a warmer temperature $\left(28^{\circ} \mathrm{C}\right)$ after 24- or 48-h exposure ( 245 and $370 \mathrm{mU} / \mathrm{mL}$ respectively). However, this enzymatic activity was reduced from 81.9 to $83.8 \mathrm{mU} / \mathrm{mL}$ at room temperature after $48 \mathrm{~h}$. When compared to the control at room temperature, furosemide and tramadol caused a noticeable reduction in A. salina AChE activity (19-24\%), whereas the exposure to hydrochlorothiazide had no significant effect (Figure 6a). The latter contaminant displayed a negative impact on enzyme activity by decreasing it to $49 \mathrm{mU} / \mathrm{mL}$ (room temperature) or $101.6 \mathrm{mU} / \mathrm{mL}\left(28^{\circ} \mathrm{C}\right)$ only after $48 \mathrm{~h}$ of exposure. Regarding the influence of temperature on contaminants effects, it was observed that AChE was in general reduced (10-74\%) in the test treatments at $28^{\circ} \mathrm{C}$ in comparison with those exposed to the same contaminants at room temperature. Reduction in $\mathrm{AChE}$ activity in different aquatic species (crustaceans, mollusks, and fish) has been reported after exposure to different contaminants, such as benzoylecgonine [68], acetaminophen [75], fluoxetine [76], among others. However, an increment in AChE has also been reported at high-temperature conditions [77]. In the present study, AChE activity tended to decrease in the presence of all emerging contaminants tested. However, time of exposure and temperature clearly influenced the impacts (i.e., hydrochlorothiazide at room temperature and $28^{\circ} \mathrm{C}$, after 24- and 48-h exposure). The changes observed for AChE in the first $24 \mathrm{~h}$ may be related to the deposition/metabolization rate of the pollutant in the tissue, enzymatic 
restoration after pollutant excretion, and the impact of the metabolites produced for each substance during the experiments $[68,76]$.
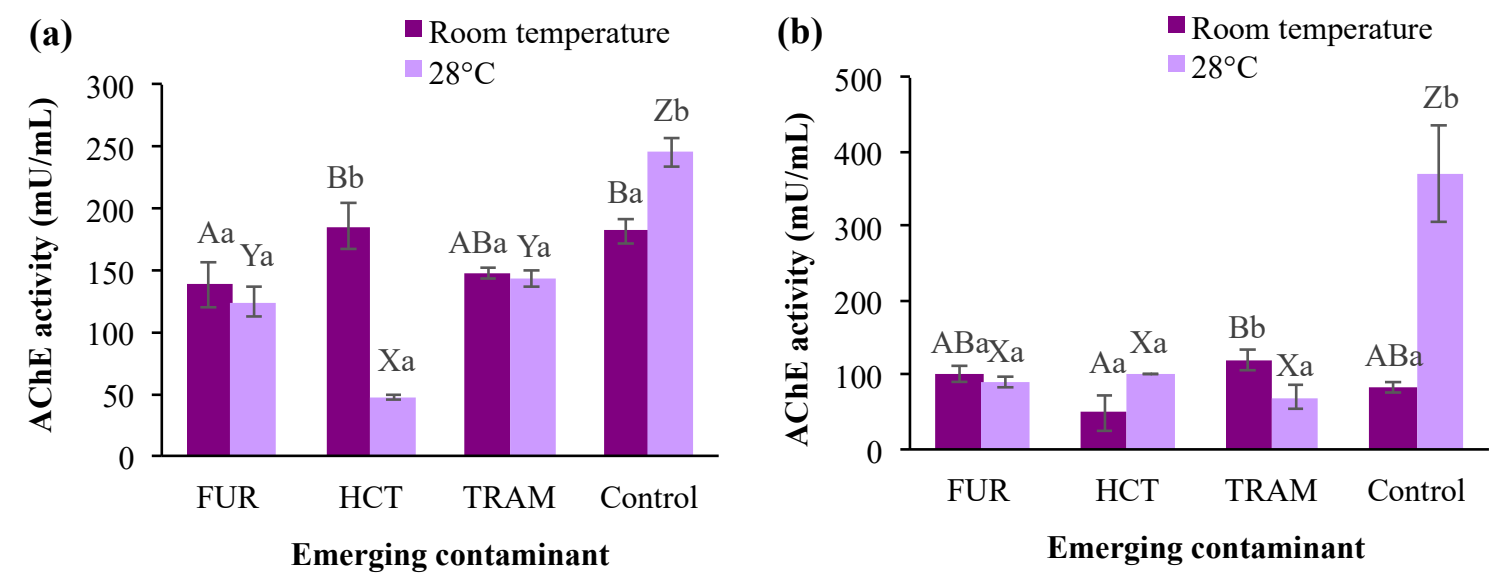

Figure 6. Acetylcholinesterase (AChE) activity in A. salina nauplii exposed to furosemide (FUR), hydrochlorothiazide (HCT), tramadol (TRAM) and uncontaminated control during (a) 24 and (b) $48 \mathrm{~h}$ at room temperature and $28^{\circ} \mathrm{C}$. Columns with the same capital letter (A, B, X, Y, and Z) are not significantly different $(\alpha=0.05)$ among the tested compounds, and means with the same lowercase letter $(\mathbf{a}, \mathbf{b})$ are not significantly different $(\alpha=0.05)$ with respect to temperature conditions. Values are expressed as mean \pm SEM $(n=3)$.

Interestingly, a similar trend was observed in GST, GPX, LDH, and AChE activities of nauplii exposed to the different emerging contaminants after $48 \mathrm{~h}$. Treatment with tramadol resulted in a variable decrease in enzyme activity levels as the temperature increased. Hydrochlorothiazide caused an enzymatic induction at $28^{\circ} \mathrm{C}$ compared with the test performed at room temperature. Furosemide also tended to reduce activity for the majority of the enzymes analyzed, but not GPx, which was increased by a warmer temperature.

In addition to the biomarkers here analyzed, others might be used to evaluate the aquatic ecosystem health such as biliary fluorescent aromatic compounds (FACs), cytochrome P4501A, ethoxyresorufin-o-deethylase, aryl hydrocarbon hydroxylase, vitellogenin, metallothioneins, heat-shock proteins, circulating hormone levels, DNA repair enzymes, PAH-DNA adducts, triglyceride levels, growth hormones, and others [78]. However, Jemec et al. [79] suggested that the use of biochemical markers is more appropriate for hazard identification than for the assessment of environmental risks or regulatory purposes. These markers are not always as sensitive as the whole organism responses, and also because some other factors (e.g., duration of exposure, environmental conditions, test species, etc.) affect the final results. The present study demonstrates this effect, as enzymatic activity levels in A. salina varied depending on the chemical, exposure time, and environmental conditions.

\section{Conclusions}

Our results demonstrate that different ECs are present in the effluent from the WWTP of Prague. This raises questions like whether the concentrations of these contaminants are safe for discharge into surface water bodies, or if they could affect human health and ecological balance in the long-term, as well as if the depuration technologies applied should be modified. The three pharmaceuticals tested (furosemide, hydrochlorothiazide, and tramadol) are indeed toxic for A. salina, with toxicity varying according to the environmental conditions. Although LC50 for all three substances was much higher than the concentrations found in the secondary effluent and is above $1 \mathrm{mg} / \mathrm{L}$ (low toxicity according to US EPA) [17], these compounds are very commonly used, and their accumulative effect must not be ignored. This toxicological profile and characterization employing $A$. salina as the study model supports the current recommendations made by NORMAN and Water Europe [32] to introduce measures 
that address ECs in the Urban Waste Water Treatment Directive, and ultimately set a precedent for the regulation of ECs around the world. This study also expands the available information for the theoretical modeling of water pollution that might help in decision support for regulating certain practices, in order to preserve ecological balance. A. salina can indicate the risk of these contaminants passing to other species involved in the marine trophic chain, as it is the base of it and is able to bioaccumulate substances in its tissue [19]. If contact with small sublethal doses (e.g., LC25) after 24 and $48 \mathrm{~h}$ disrupted the cellular balance and triggered enzymatic activity (GST, GPx, LDH, AChE) to protect nauplii from oxidation and cellular damage, long-term exposure (chronic toxicity) even at lower concentrations could have the same effect, possibly even worse. Attention must be paid to these and many other ECs (including interactions between substances) and their level of toxicity for this and other indicator organisms, in case they present risk of high toxicity. Because of the extensive amount of ECs currently detected in water, characterizing their toxicity is vital for policy-makers to address and define proper water treatment protocols and start regulating their disposal and concentration in discharge. All these actions will aid a shift toward water-scarcity mitigation practices, such as utilizing reclaimed wastewater, to ensure safe future water supplies around the world.

Author Contributions: D.L.C.-C. contributed with the conceptualization, validation, and ecotoxicological tests supervision, including funding acquisition and writing/editing the manuscript. J.W. contributed with conceptualization and project supervision, funding the UHPLC-MS/MS analyses and review of the final edition of the manuscript. M.T.-S. performed the toxicity methodological procedures and statistical analyses, also the original writing of the enzymatic activity results. V.R.D.-S. responsible for the project, contributed with effluent sampling, toxicity methodological procedures, results analysis and manuscript writing. All authors have read and agreed to the published version of the manuscript.

Funding: The research described in this paper was financially supported by Consejo Nacional de Ciencia y Tecnología of Mexico (Scholarship No. 543296 and No. 2018-000008-01NACV-00090), Tecnológico de Monterrey Campus Puebla for supplying materials, facilities and funding for this research to be performed, and Technological Agency of the Czech Republic, project No. TH03030080 "Wastewater reuse in water management of the cities of the future."

Conflicts of Interest: The authors declare no conflict of interest.

\section{Acronyms}

The following acronyms and abbreviations are used in this manuscript:

$\begin{array}{ll}\text { EC } & \text { Emerging contaminant } \\ \text { PPCPs } & \text { Pharmaceuticals and personal care products } \\ \text { GST } & \text { Glutathione-S-transferase } \\ \text { GPx } & \text { Glutathione peroxidase } \\ \text { LDH } & \text { Lactate dehydrogenase } \\ \text { AChE } & \text { Acetylcholinesterase } \\ \text { WWTP } & \text { Wastewater treatment plant } \\ \text { LC50 } & \text { Lethal concentration for } 50 \% \text { of the population } \\ \text { LC25 } & \text { Lethal concentration for } 25 \% \text { of the population } \\ \text { ET } & \text { Exposure time } \\ \text { T } & \text { Temperature } \\ \text { FUR } & \text { Furosemide } \\ \text { HCT } & \text { Hydrochlorothiazide } \\ \text { TRAM } & \text { Tramadol } \\ \text { LOD } & \text { Limit of detection }\end{array}$

\section{References}

1. IWA Resource Recovery Cluster. State of the Art Compendium Report on Resource Recovery from Water; IWA International Water Association: London, UK, 2015.

2. Lapworth, D.J.; Baran, N.; Stuart, M.E.; Ward, R.S. Emerging organic contaminants in groundwater: A review of sources, fate and occurrence. Environ. Pollut. 2012, 163, 287-303. [CrossRef] [PubMed] 
3. Moreau, M.; Hadfield, J.; Hughey, J.; Sanders, F.; Lapworth, D.J.; White, D.; Civil, W. A baseline assessment of emerging organic contaminants in New Zealand groundwater. Sci. Total Environ. 2019, 686, 425-439. [CrossRef]

4. Jurado, A.; Vázquez-Suñé, E.; Carrera, J.M.; López de Alda, M.; Pujades, E.; Barceló, D. Emerging organic contaminants in groundwater in Spain: A review of sources, recent occurrence and fate in a European context. Sci. Total Environ. 2012, 440, 82-94. [CrossRef] [PubMed]

5. Tong, A.Y.C.; Peake, B.M.; Braund, R. Disposal Practices for Unused Medications around the World. Environ. Int. 2011, 37, 292-298. [CrossRef] [PubMed]

6. Zwart, N.; Jonker, W.; ten Broek, R.; de Boer, J.; Somsen, G.; Kool, J.; Hamers, T.; Houtman, C.J.; Lamoree, M.H. Identification of mutagenic and endocrine disrupting compounds in surface water and wastewater treatment plant effluents using high-resolution effect-directed analysis. Water Res. 2020, 168, 115204. [CrossRef] [PubMed]

7. Persoone, G.; Wells, P.G. Artemia in aquatic toxicology: A review. In Artemia Research and Its Applications. Morphology, Genetics, Strain Characterization Toxicology; Sorgeloos, P., Ed.; Universita Press: Wetteren, Belgium, 1987; pp. 259-275.

8. Rajabi, S.; Ramazani, A.; Hamidi, M.; Naji, T. Artemia salina as a model organism in toxicity assessment of nanoparticles. DARU 2015, 23, 20. [CrossRef]

9. Vosylienè, M.Z. Review of the methods for acute and chronic toxicity assessment of single substances, effluents and industrial waters. Acta Zool. Lit. 2007, 17, 3-15. [CrossRef]

10. US EPA. Methods for Measuring the Acute Toxicity of Effluents and Receiving Waters to Freshwater and Marine Organisms; EPA-821-R-02-012; US Environmental Protection Agency: Washington, DC, USA, 2002.

11. Bustos-Obregon, E.; Vargas, Á. Chronic toxicity bioassay with populations of the crustacean Artemia salina exposed to the organophosphate diazinon. Biol. Res. 2010, 43, 357-362. [CrossRef]

12. Roy, B.; Krishnan, S.P.; Chandrasekaran, N.; Mukherjee, A. Toxic effects of engineered nanoparticles (metal/metal oxides) on plants using Allium cepa as a model system. In Comprehensive Analytical Chemistry; Elsevier: Vellore, India, 2019; Volume 84, pp. 313-359.

13. Eurostat. Population on 1 January by Five-Year Age Group, Sex and Metropolitan Regions. Available online: http://appsso.eurostat.ec.europa.eu/nui/show.do?dataset=met_pjangrp3\&lang=en (accessed on 24 January 2020).

14. Kozisek, F.; Pomykacova, I.; Jeligova, H.; Cadek, V.; Svobodova, V. Survey of human pharmaceuticals in drinking water in the Czech Republic. J. Water Health 2013, 11, 84-97. [CrossRef]

15. Rozman, D.; Hrkal, Z.; Váňa, M.; Vymazal, J.; Boukalová, Z. Occurrence of pharmaceuticals in wastewater and their interaction with shallow aquifers: A case study of Horní Beřkovice, Czech Republic. Water 2017, 9 , 218. [CrossRef]

16. Ponto, L.L.B.; Schoenwald, R.D. Furosemide (frusemide) a pharmacokinetic/pharmacodynamic review (part I). Clin. Pharmacokinet. 1990, 18, 381-408. [PubMed]

17. Carter, B.L.; Ernst, M.E.; Cohen, J.D. Hydrochlorothiazide versus chlorthalidone: Evidence supporting their interchangeability. Hypertension 2004, 43, 4-9. [CrossRef]

18. Lehmann, K.A. Tramadol for the management of acute pain. Drugs 1994, 47, 19-32. [CrossRef] [PubMed]

19. Varó, I.; Amat, F.; Navarro, J.C.; Barreda, M.; Pitarch, E.; Serrano, R. Assessment of the efficacy of Artemia sp (Crustacea) cysts chorion as barrier to chlorpyrifos (organophosphorus pesticide) exposure. Effect on hatching and survival. Sci. Total Environ. 2006, 366, 148-153. [CrossRef] [PubMed]

20. Horáková, M.; Kollerová, L.; Ptáková, H. Analytika Vody, 2nd ed.; Sykora, V., Ed.; Vydavatelství VŠCHT Praha: Praha, Czechia, 2007. (In Czech)

21. US EPA. Method 1694: Pharmaceuticals and Personal Care Products in Water, Soil, Sediment, and Biosolids by HPLC/MS/MS; US Environmental Protection Agency: Washington, DC, USA, 2007.

22. Habig, W.H.; Pabst, M.J.; Jakoby, W.B. Glutathione S-transferases the first enzymatic step in mercapturic acid formation. J. Biol. Chem. 1974, 249, 7130-7139. [PubMed]

23. Loos, R.; Carvalho, R.; António, D.C.; Comero, S.; Locoro, G.; Tavazzi, S.; Paracchini, B.; Ghiani, M.; Lettieri, T.; Blaha, L.; et al. EU-wide monitoring survey on emerging polar organic contaminants in wastewater treatment plant effluents. Water Res. 2013, 47, 6475-6487. [CrossRef]

24. Minguez, L.; Pedelucq, J.; Farcy, E.; Ballandonne, C.; Budzinski, H.; Halm-Lemeille, M.P. Toxicities of 48 pharmaceuticals and their freshwater and marine environmental assessment in northwestern France. Environ. Sci. Pollut. Res. 2016, 23, 4992-5001. [CrossRef] 
25. Brausch, J.M.; Connors, K.A.; Brooks, B.W.; Rand, G.M. Human Pharmaceuticals in the Aquatic Environment: A Review of Recent Toxicological Studies and Considerations for Toxicity Testing. In Reviews of Environmental Contamination and Toxicology; Whitacre, D., Ed.; Springer: Boston, MA, USA, 2012; Volume 218, pp. 1-100.

26. Vymazal, J.; Březinová, T.D.; Koželuh, M.; Kule, L. Occurrence and removal of pharmaceuticals in four full-scale constructed wetlands in the Czech Republic-The first year of monitoring. Ecol. Eng. 2017, 98, 354-364. [CrossRef]

27. Anumol, T.; Wu, S.; Marques dos Santos, M.; Daniels, K.D.; Snyder, S.A. Rapid direct injection LC-MS/MS method for analysis of prioritized indicator compounds in wastewater effluent. Environ. Sci. Water Res. Technol. 2015, 1, 632-643. [CrossRef]

28. Rogowska, J.; Cieszynska-Semenowicz, M.; Ratajczyk, W.; Wolska, L. Micropollutants in treated wastewater. Ambio 2020, 49, 487-503. [CrossRef]

29. Leclercq, M.; Mathieu, O.; Gomez, E.; Casellas, C.; Fenet, H.; Hillaire-Buys, D. Presence and fate of carbamazepine, oxcarbazepine, and seven of their metabolites at wastewater treatment plants. Arch. Environ. Contam. Toxicol. 2009, 56, 408-415. [CrossRef] [PubMed]

30. EU Environmental Implementation Review 2019. Country Report-CZECH REPUBLIC. Brussels, Belgium. 2019. Available online: https://ec.europa.eu/environment/eir/pdf/report_cz_en.pdf (accessed on 23 March 2020).

31. Golovko, O.; Kumar, V.; Fedorova, G.; Randak, T.; Grabic, R. Seasonal changes in antibiotics, antidepressants/ psychiatric drugs, antihistamines and lipid regulators in a wastewater treatment plant. Chemosphere 2014, 111, 418-426. [CrossRef] [PubMed]

32. NORMAN. Contaminants of Emerging Concern in Urban Wastewater Joint NORMAN and Water Europe Position Paper 2019. Available online: https://www.normandata.eu/sites/default/files/files/Publications/Position\% 20paper_CECs\%20UWW_NORMAN_WE_2019_Final_20190910_public.pdf (accessed on 20 March 2020).

33. Directive, E.U.W. Council Directive of 21. May 1991 concerning urban waste water treatment (91/271/EEC). J. Eur. Commun. 1991, 34, 40.

34. Wang, J.; Wang, S. Activation of persulfate (PS) and peroxymonosulfate (PMS) and application for the degradation of emerging contaminants. Chem. Eng. J. 2018, 334, 1502-1517. [CrossRef]

35. Beretta, M.; Perelo, L.W.; de Oliveira, I.B. Quantification and toxicity testing of pharmaceuticals in tropical marine sediments. In Microorganisms in Industry and Environment: From Scientific and Industrial Research to Consumer Products; Antonio, M.V., Ed.; All Saints Bay: Bahia, Brazil, 2011; pp. 187-191.

36. Meyer, B.N.; Ferrigni, N.R.; Putnam, J.E.; Jacobsen, L.B.; Nichols, D.J.; McLaughlin, J.L. Brine shrimp: A convenient general bioassay for active plant constituents. Planta Med. 1982, 45, 31-34. [CrossRef] [PubMed]

37. Rizzo, L.; Meric, S.; Kassinos, D.; Guida, M.; Russo, F.; Belgiorno, V. Degradation of diclofenac by TiO2 photocatalysis: UV absorbance kinetics and process evaluation through a set of toxicity bioassays. Water Res. 2009, 43, 979-988. [CrossRef] [PubMed]

38. Migliore, L.; Civitareale, C.; Brambilla, G.; Di Delupis, G.D. Toxicity of several important agricultural antibiotics to Artemia. Water Res. 1997, 31, 1801-1806. [CrossRef]

39. Xu, X.; Lu, Y.; Zhang, D.; Wang, Y.; Zhou, X.; Xu, H.; Mei, Y. Toxic assessment of triclosan and triclocarban on Artemia salina. Bull. Environ. Contam. Toxicol. 2015, 95, 728-733. [CrossRef]

40. García, J.L.; Santacruz-Vázquez, V.; Valera, M.; Moreira, M.; Cardenas-Chavez, D.; Tapia-Salazar, M.; Torres, E. Oxidation of Flame Retardant Tetrabromobisphenol A by a Biocatalytic Nanofiber of Chloroperoxidase. Int. J. Environ. Res. Public Health 2019, 16, 4917. [CrossRef]

41. Vanhaecke, P.; Siddall, S.E.; Sorgeloos, P. International study on Artemia. XXXII. Combined effects of temperature and salinity on the survival of Artemia of various geographical origin. J. Exp. Mar. Biol. Ecol. 1984, 80, 259-275. [CrossRef]

42. Gajardo, G.M.; Beardmore, J.A. The Brine Shrimp Artemia: Adapted to Critical Life Conditions. Front. Physiol. 2012, 3, 185. [CrossRef] [PubMed]

43. Wear, R.G.; Haslett, S.J. Effects of temperature and salinity on the biology of Artemia franciscana Kellogg from lake Grassmere, New Zealand. 1. Growth and mortality. J. Exp. Mar. Biol. Ecol. 1986, 98, 153-166. [CrossRef]

44. Persoone, G.; Van de Vel, A.; Van Steertegem, M.; De Nayer, B. Predictive value of laboratory tests with aquatic invertebrates: Influence of experimental conditions. Aquat. Toxicol. 1989, 14, 149-167. [CrossRef]

45. Isidori, M.; Nardelli, A.; Parrella, A.; Pascarella, L.; Previtera, L. A multispecies study to assess the toxic and genotoxic effect of pharmaceuticals: Furosemide and its photoproduct. Chemosphere 2006, 63, 785-793. [CrossRef] [PubMed] 
46. Dong, Z.; Senn, D.B.; Moran, R.E.; Shine, J.P. Prioritizing environmental risk of prescription pharmaceuticals. Regul. Toxicol. Pharm. 2013, 65, 60-67. [CrossRef] [PubMed]

47. Pascoe, D.; Karntanut, W.; Muller, C.T. Do pharmaceuticals affect freshwater invertebrates? A study with the cnidarians Hydra vulgaris. Chemosphere 2003, 51, 521-528. [CrossRef]

48. Martins, A.; Guimarães, L.; Guilhermino, L. Chronic toxicity of the veterinary antibiotic florfenicol to Daphnia magna assessed at two temperatures. Environ. Toxicol. Pharmacol. 2013, 36, 1022-1032. [CrossRef]

49. Li, A.J.; Leung, P.T.Y.; Bao, V.W.W.; Yi, A.X.L.; Leung, K.M.Y. Temperature-dependent toxicities of four common chemical pollutants to the marine medaka fish, copepod and rotifer. Ecotoxicology 2014, 23, 1564-1573. [CrossRef]

50. Patra, R.W.; Chapman, J.C.; Lim, R.P.; Gehrke, P.C.; Sunderam, R.M. Interactions between water temperature and contaminant toxicity to freshwater fish. Environ. Toxicol. Chem. 2015, 34, 1809-1817. [CrossRef]

51. Maulvault, A.L.; Camacho, C.; Barbosa, V.; Alves, R.; Anacleto, P.; Fogaça, F.; Kwadijk, C.; Kotterman, M.; Cunha, S.C.; Fernandes, J.O.; et al. Assessing the effects of seawater temperature and $\mathrm{pH}$ on the bioaccumulation of emerging chemical contaminants in marine bivalves. Environ. Res. 2018, 161, 236-247. [CrossRef]

52. Lannig, G.; Cherkasova, A.S.; Sokolova, I.M. Temperature-dependent effects of cadmium on mitochondrial and whole-organism bioenergetics of oysters (Crassostrea virginica). Mar. Environ. Res. 2006, 62, 79-82. [CrossRef] [PubMed]

53. Slotsbo, S.; Heckmann, L.H.; Damgaard, C.; Roelofs, D.; de Boer, T.; Holmstrup, M. Exposure to mercury reduces heat tolerance and heat hardening ability of the springtail Folsomia candida. Comp. Biochem. Physiol. C 2009, 150, 118-123. [CrossRef]

54. Alcock, R.E.; Sweetman, A.; Jones, K.C. Assessment of organic contaminant fate in wastewater treatment plants I: Selected compounds and physicochemical properties. Chemosphere 1999, 38, 2247-2262. [CrossRef]

55. US EPA; Estimation Program Interface (EPI). Retrieved from PubChem. Available online: https://pubchem. ncbi.nlm.nih.gov/source/hsdb/7047 (accessed on 4 February 2020).

56. Yalkowsky, S.H.; He, Y.; Jain, P. Handbook of Aqueous Solubility Data, 2nd ed.; CRC Press: Boca Raton, FL, USA, 2010; p. 866.

57. Jakimska, A.; Śliwka-Kaszyńska, M.; Reszczyńska, J.; Namieśnik, J.; Kot-Wasik, A. Elucidation of transformation pathway of ketoprofen, ibuprofen, and furosemide in surface water and their occurrence in the aqueous environment using UHPLC-QTOF-MS. Anal. Bioanal. Chem. 2014, 406, 3667-3680. [CrossRef] [PubMed]

58. Brigante, M.; DellaGreca, M.; Previtera, L.; Rubino, M.; Temussi, F. Degradation of hydrochlorothiazide in water. Environ. Chem. Lett. 2005, 2, 195-198. [CrossRef]

59. Rúa-Gomez, P.C.; Puettmann, W. Degradation of lidocaine, tramadol, venlafaxine and the metabolites O-desmethyltramadol and O-desmethylvenlafaxine in surface waters. Chemosphere 2013, 90, 1952-1959. [CrossRef]

60. DellaGreca, M.; Fiorentino, A.; Iesce, M.R.; Isidori, M.; Nardelli, A.; Previtera, L.; Temussi, F. Identification of phototransformation products of prednisone by sunlight: Toxicity of the drug and its derivatives on aquatic organisms. Environ. Toxicol. Chem. 2003, 22, 534-539. [CrossRef]

61. Prasath, A.; Panneerselvan, L.; Provatas, A.; Naidu, R.; Megharaj, M. Genotoxicity assessment of acute exposure of 2,4-dinitroanisole, its metabolites and 2,4,6-trinitrotoluene to Daphnia carinata. Ecotoxicology 2016, 25, 1873-1879. [CrossRef]

62. Papadopoulos, A.I.; Lazaridou, E.; Mauridou, G.; Touraki, M. Glutathione S-transferase in the branchiopod Artemia salina. Mar. Biol. 2004, 144, 295-301. [CrossRef]

63. Grammou, A.; Papadimitriou, C.; Samaras, P.; Vasara, E.; Papadopoulos, A.I. Effect of municipal wastewater effluent upon the expression of Glutathione S-transferase isoenzymes of brine shrimp Artemia. Chemosphere 2011, 84, 105-109. [CrossRef]

64. Oliveira, L.L.D.; Antunes, S.C.; Gonçalves, F.; Rocha, O.; Nunes, B. Evaluation of ecotoxicological effects of drugs on Daphnia magna using different enzymatic biomarkers. Ecotoxicol. Environ. Saf. 2015, 119, $123-131$. [CrossRef] [PubMed]

65. Muthukumar, K.; Nachiappan, V. Cadmium-induced oxidative stress in Saccharomyces cerevisiae. Indian J. Biochem. Biophys. 2010, 47, 383-387. [PubMed]

66. Nunes, B.; Carvalho, F.; Guilhermino, L. Effects of widely used pharmaceuticals and a detergent on oxidative stress biomarkers of the crustacean Artemia parthenogenetica. Chemosphere 2006, 62, 581-594. [CrossRef] [PubMed] 
67. Lushchak, V.I.; Bagnyukova, T.V. Temperature increase results in oxidative stress in goldfish tissues. 2. Antioxidant and associated enzymes. Comp. Biochem. Phys. C 2006, 143, 36-41. [CrossRef] [PubMed]

68. Parolini, M.; De Felice, B.; Ferrario, C.; Salgueiro-González, N.; Castiglioni, S.; Finizio, A.; Tremolada, P. Benzoylecgonine exposure induced oxidative stress and altered swimming behavior and reproduction in Daphnia magna. Environ. Pollut. 2018, 232, 236-244. [CrossRef] [PubMed]

69. Parveen, S.; Bharose, R.; ve Singh, D. Effect of tannery waste water on lactate dehydrogenase (LDH) enzyme activity of fresh water fish, Channa punctatus. J. Entomol. Zool. Stud. 2017, 5, 643-647.

70. Rema, L.P.; Babu, P. Effect of mercury and zinc on some metabolically important enzymes of Oreochromis mossambicus. Indian J. Mar. Sci. 2012, 41, 317-380.

71. Criel, G.R.; Macrae, T.H. Artemia morphology and structure. In Artemia: Basic and Applied Biology, 1st ed.; Abatzopoulos, T.J., Beardmore, J.A., Clegg, J.S., Sorgeloos, P., Eds.; Springer: Dordrecht, The Netherlands, 2012; pp. 1-37.

72. Kobayashi, N.; Taniguchi, N.; Sako, F.; Takakuwa, E. A screening method for the toxicity of food dyes using Artemia salina larvae. J. Toxicol. Sci. 1977, 2, 383-390. [CrossRef]

73. Fu, H.; Xia, Y.; Chen, Y.; Xu, T.; Xu, L.; Guo, Z.; Xu, H.; Xie, H.Q.; Zhao, B. Acetylcholinesterase Is a Potential Biomarker for a Broad Spectrum of Organic Environmental Pollutants. Environ. Sci. Technol. 2018, 52, 8065-8074. [CrossRef]

74. De Lange, H.J.; Peeters, E.; Lurling, M. Changes in Ventilation and Locomotion of Gammarus pulex (Crustacea, Amphipoda) in Response to Low Concentrations of Pharmaceuticals. Hum. Ecol. Risk Assess. 2009, 15, 111-120. [CrossRef]

75. Solé, M.; Shaw, J.P.; Frickers, P.E.; Readman, J.W.; Hutchinson, T.H. Effects on feeding rate and biomarker responses of marine mussels experimentally exposed to propranolol and acetaminophen. Anal. Bioanal. Chem. 2009, 396, 649-656. [CrossRef] [PubMed]

76. Ding, J.; Zou, H.; Liu, Q.; Zhang, S.; Razanajatovo, R.M. Bioconcentration of the antidepressant fluoxetine and its effects on the physiological and biochemical status in Daphnia magna. Ecotoxicol. Environ. Saf. 2017, 142, 102-109. [CrossRef] [PubMed]

77. Pfeifer, S.; Schiedek, D.; Dippner, J.W. Effect of temperature and salinity on acetylcholinesterase activity, a common pollution biomarker, in Mytilus sp. from the south-western Baltic Sea. J. Exp. Mar. Biol. Ecol. 2005, 320, 93-103. [CrossRef]

78. Hook, S.E.; Gallagher, E.P.; Batley, G.E. The role of biomarkers in the assessment of aquatic ecosystem health. Integr. Environ. Assess. 2014, 10, 327-341. [CrossRef]

79. Jemec, A.; Drobne, D.; Tišler, T.; Sepčić, K. Biochemical biomarkers in environmental studies—Lessons learnt from enzymes catalase, glutathione S-transferase and cholinesterase in two crustacean species. Environ. Sci. Pollut. Res. 2009, 17, 571-581. [CrossRef]

(C) 2020 by the authors. Licensee MDPI, Basel, Switzerland. This article is an open access article distributed under the terms and conditions of the Creative Commons Attribution (CC BY) license (http://creativecommons.org/licenses/by/4.0/). 